\title{
Kernos
}

Revue internationale et pluridisciplinaire de religion grecque antique

$14 \mid 2001$

Varia

\section{Rhapsodizing Orpheus}

\section{Richard P. Martin}

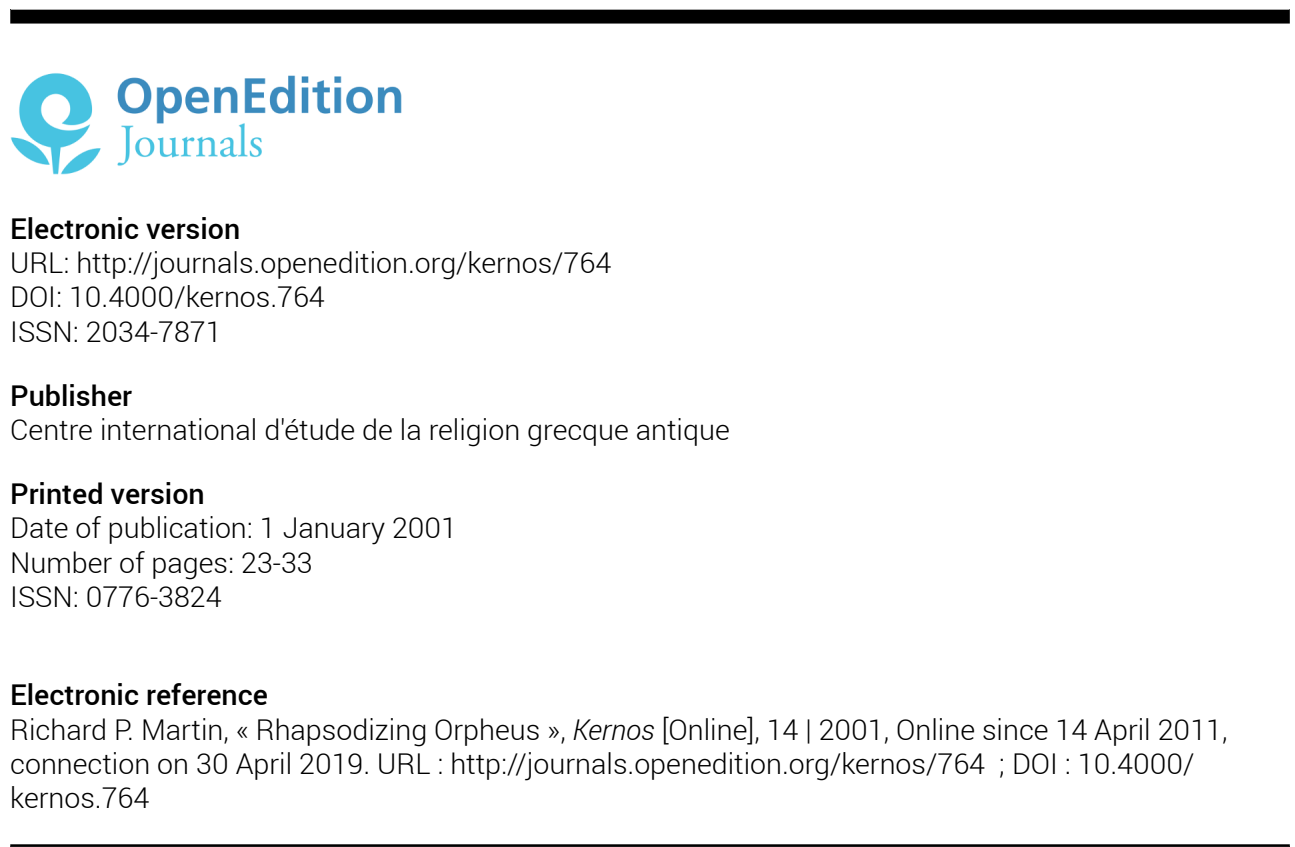

Kernos 


\section{Rhapsodizing Orpheus}

Orpheus - we know him as a poet, a musician, and a myth. Yet we must recall that all three of these media - poetry, music, and myth - arise, at some point, out of an act of performance. The last-mentioned, mutbos, can in fact be described from Homer on as the very paradigm for performance in archaic Greece: a public utterance that seeks through persuasive means to negotiate authority before a critical audience. ${ }^{1}$ In this connection, it should be worth asking: exactly what sorts of performances originated and transmitted the figure of Orpheus? ${ }^{2}$

To begin with, it is clear that, in archaic Greece, cult and ritual provided a site for audiences and performers to comment on this multivalent figure. Such occasions even made use of hymnic poetry that had been attributed to the Thracian singer. There are a number of testimonia, such as the report by Pausanias (IX, 27, 2; cf. IX, 30, 12) that the Lykomidai of Phlya sang Orphic hymns to accompany rituals. Fritz Graf has thoroughly investigated the interrelation of Orpheus, Musaios, and the Eumolpidai at Eleusis. ${ }^{3}$ However, we might be misled by the ancient evidence into thinking that private gatherings, thiasoi, or initiate groups were the only or even the major locus to feature Orphic poetic performances. ${ }^{4}$ But this need not be the full picture. I will argue instead that Orphic poetry, whatever its private affiliations, formed part of the rhapsode's repertoire. If we assume Orphic poems played a part in this very public kind of performance, it can help clarify and explain several hitherto unconnected phenomena in ancient myth and poetics.

To sharpen the point about performance, let me first juxtapose two quotations, one from Martin West, the other from Plato. While discussing the apparently unusual status of the Derveni commentator, West makes the

1 See R. MARTIN, The Language of Heroes: Speech and Performance in the Iliad. Ithaca, 1989; C. Calame, "Muthos, logos et histoire", L'Homme 147 (1998), p. 127-149; G. NAGY, Homeric Questions, Austin, 1996, p. 113-152.

2 This paper originated as a contribution to the annual gathering of the Coralie consortium, held May 24-26, 2000, at Lausanne. It is a pleasure to thank Claude Calame and the members of this scholarly thiasos for advice and encouragement.

3 Fr. Graf, Eleusis und die orphiscbe Dicbtung Atbens in vorbellenistischer Zeit, Berlin, 1974.

4 On these, see M. WEST, The Orpbic Poems, Oxford, 1983, p. 79, 260-263. 
following more general statement: "While not secret, Orphic poems seem to have had a very limited circulation. They were not a matter of general public interest. They were not taught in school or recited for public or social entertainment." ${ }^{5}$ West, of course, approaches the Orphic material from a relentlessly literary point-of-view. He thinks in terms of texts, in terms of circulation of scrolls, and in terms of copying and borrowing from books. Even his imagined historical sketch for the intrusion of messy Asiatic rites into Greece calls to mind descriptions of the advent of a genteel neopaganism in prim Edwardian Britain. Perhaps we need to apply a somewhat less anachronistic model. If, as West argues, Orphic poetry was so private, we must then ask: how can Plato describe it in terms of a broad audience's competence to judge performances? For this is what Plato seems to be saying at Ion 533b-c:

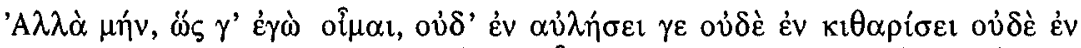

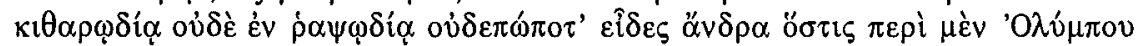

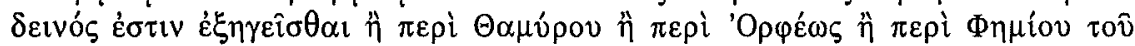

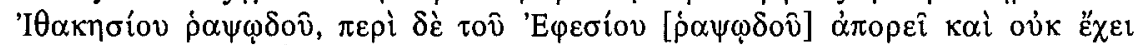

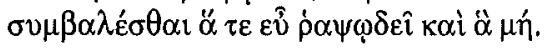

But surely, I think, you never saw a man, when it came to aulos-playing, kithara-playing, singing to the kithara or rhapsodizing who is clever at performing an explanation (exêgeisthai) about Olympos or Thamyris or Orpheus or Phemios the Ithacan rhapsode yet is clueless about Ion of Ephesos and cannot find anything to say concerning what he rhapsodizes well and what not.

Are we meant to assume that Socrates in the Ion is talking about a much more elite esoteric art of proto-literary criticism? If so, how do we reconcile his comment with the obvious point he is making - that Ion, a public rhapsodic performer, who acts in front of perhaps 20,000 people, can be judged on the same level as the legendary stars of kitharodic and aulic art? It is far easier to interpret this passage as an allusion to the practices within contemporary "performances" by players and singers who attributed their materials - however they might have creatively changed them - to the bigname artists of the mythic past. The inclusion of aulos performance in Socrates' comment is the key piece of evidence for this argument, for even if musical notation existed, how could anyone in the late 5th century BCE have judged the performance of a given player, unless this performance continued to be something live, that is to say a re-performance that projected itself back onto an Olympos, Orpheus or Thamyris? We shall return to this point at the end, when I come to talk of other mythic projections.

It may be true that we lack direct evidence that tells us unequivocally how rhapsodes included Orphic poetry in their performances. But this does

5 WEST, o.c. 
not prevent us from interrogating the indirect evidence that exists. In what follows, I shall take an oblique approach to the problem, by looking first at poetry we certainly know was in the rhapsodic repertoire - Homeric and Hesiodic verse. I will be focussing in particular on the "catalogues of women" that appear in both corpora, and on some related codicological evidence. Then we might return to Orpheus, the performer and the myth.

The indirect approach forces us to touch briefly on a larger theoretical issue: intertextuality. The problems and delights arising from intertextuality, so familiar from later literature, appear within archaic Greek poetry as well, although this poetry in all likelihood is the result of oral composition-inperformance. Unfortunately, two modes have dominated the criticism of such poetry, and affected especially the issue of intertextual relations. In the specific cases where Homer and Hesiod show close resemblances we can find: 1) a positivist, "genetic" approach that insists on reconstructing influences and uses textuality as its paradigm (Homer "read" Hesiod or vice versa) and 2) a generic approach - for example, one could claim that Homer and Hesiod both made use of pre-existing "catalogue poetry". 6

Both approaches of course have a perfectly legitimate ancestry within our discipline - these are, after all, the working assumptions behind stemmatology and dialectology. In the study of poetics they leave something to be desired. While the second method is a good deal better than the first, it is still not as fruitful as a third possible avenue of approach - which I propose now - i.e. the study of intertextual effects via performance. Or, if we need a more appropriate term, "performance interaction." By this I mean that, even in the context of live oral composition, it is possible for one performer to "allude" to and even "quote" other traditions known to him and recognized by the audience. Furthermore, it is possible in such situations to make a point by the use of the "quoted" material in question. Again, I am arguing that all this can be done without any textualization. ${ }^{7}$

In Odyssey XI, 225ff. generations of critics have seen resemblances to the style of the Hesiodic Catalogue of Women. Some passages match scraps of the Catalogue verbatim. Take, for example, the conversation between Poseidon and his lover Tyro (fr. $31 \mathrm{M}-\mathrm{W}$ ):

6 Examples of the first abound in Analyst critiques of Homer; I have tried the second, "generic", approach in order to resolve a problem in Hesiod Works and Days and Odyssey Bk. VIII: see R. Martin, "Hesiod, Odysseus, and the Instruction of Princes", $T A P b A 114$ (1984), p. 29-48, with further bibliography on both methods.

7 Further work on this set of issues includes P. Pucci, Odysseus Polutropos, Ithaca, 1987; R. Martin, "Wrapping Homer Up", in A. Sharrock, H. Morales (eds.), Intratextuality, Oxford, 2000, p. 43-65; M. KonEnJak, "Homerische Intertextualität ohne Formeln?", $M D$ 40 (1998), p. 133-143. Less confident about the sort of procedure I am sketching is K. Dowden, "Homer's Sense of Text", JHS 116 (1996), p. 47-61. 


\section{P. Tebt. 271, ed. Grenfell-Hunt}

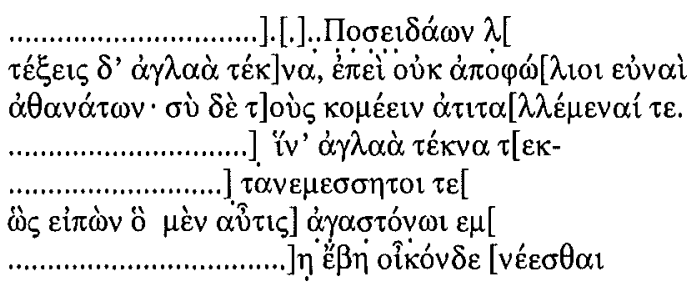

Grenfell and Hunt, the original editors of the papyrus, thought in fact that this was a scrap of prose commentary on the Odyssey; Vitelli believed it was a piece of cyclic epic; in 1937 Pfeiffer identified it on the basis of content and style as coming from the Hesiodic Catalogue. Already in 1884, however, Wilamowitz, working from other transmitted fragments and some Berlin papyri, had seen the resemblances between the Hesiodic and Homeric Frauenkataloge and had begun the game of assigning priority: he favored Hesiod as the source for Homer since he claimed that the Catalogue was not motivated within the Odyssey episode and had no inherent connection with the hero. ${ }^{8}$

We cannot enter into the century-long debate that ensued. Given the methods implicit in priority-hunting (subjective evaluation based on impressions of style, dating by assumptions about content and attitude, etc.) we can expect indefinite results. And that is what we are given in Heubeck's contribution to the Oxford Odyssey commentary. In brief, he thinks the catalogue is probably an interpolation, but to remove it would require deeper cuts into the fabric of the narrative.?

If we shift methodology, however, and follow a performance approach, the Catalogue style in Odysseus' recounting of his katabasis becomes something rather new. Instead of a sign of textual untidiness, to be excused or mopped up, it is a key moment where the poet characterizes his own performance at the same time as he represents the ability and cunning of his internal narrator, Odysseus. And this will be relevant to our view of Orphic poetry as well.

No one, it seems, has asked what it means that the character/narrator Odysseus is represented as performing precisely this kind of catalogue poetry within the Odyssey. Some excellent work, has been done, however, on the pragmatics of the so-called "intermezzo." Lillian Doherty makes the point that the catalogue of heroines is calculated to please the Phaeacian

8 U. VON WILAMOWITZ-MOELLENDORFF, Homeriscbe Untersucbungen, Berlin, 1884; R. Pfeiffer, "Hesiodisches und Homerisches", Pbilologus 92 (1937), p. 1-18. In general see M. West, The Hesiodic Catalogue of Women, Oxford, 1985, ad loc.

9 A. Heubeck, A. Hoekstra, A Commentary on Homer's Odyssey II, Oxford, 1989 (Italian original: Rome 1983) ad loc.; see also D. PAGE, The Homeric Odyssey, Oxford, 1955, p. $20-51$. 
queen Arete; Odysseus' interruption of his narrative, and his suggestion that it is time for all to go to bed, prompts her (rather than her husband) to get the Phaeacians to offer more guest gifts. Doherty compares Odysseus to Scheherezade. There are no dire consequences in this version, but the hero does end up playing on the audience's curiosity precisely to reap rewards; because Odysseus knows his audience is a gendered one, he slyly produces a story with special emphasis on the fates and virtues of women. ${ }^{10}$

William Wyatt makes a similar point: he further adduces evidence from 19th century Istanbul about wandering minstrels, the mettagh, who collect their money just when the action of the narrative is becoming intense - to see whether the audience is seriously interested in getting to the really good stories. We might view this behavior as a classic hustle. For Wyatt, the enthralling material comprises the coming encounter with Trojan War veterans; the Catalogue itself is more of a tease. Both he and Doherty recognize that the nice detail of a story-teller getting paid inside the poem has a certain resonance for a real audience facing a real performer. ${ }^{11}$

More details could be added from comparative studies to show how closely Odysseus' strategy resembles an oral poet's. ${ }^{12}$ But let us explore the contextual hints a bit further here. When we take into consideration the precise deployment of motifs and their timing within Odyssey Bk. 11, it emerges that Odysseus resembles not just any generic oral poet: he works like a rbapsode. For Odysseus uses a Catalogue of Women in the way that real rhapsodes must have been using the genre in actual performances, probably around the end of the 6th century. In referring to rhapsodes as creative interpreters and re-performers of a poetic tradition, I am following the lead of Gregory Nagy, who has examined the evidence in full. ${ }^{13}$

We know that catalogue material in general had a sort of optional status for some later scribes. A small group of Iliad papyri and manuscripts, for instance - but one that includes the important Townleianus - omits the Catalogue of Ships altogether; three manuscripts place it after Book 24 of the poem. ${ }^{14}$ The Townleianus, meanwhile, preserves a scholion that indicates

10 L. DoherTy, "The Internal and Implied Audiences of Odyssey 11", Aretbusa 24 (1991), p. 145-176.

11 W. WyatT, "The Intermezzo of Odyssey 11 and the Poets Homer and Odysseus", SMEA 27 (1989), p. 235-253; see also on the thematics of the Catalogue, see J. Houl.iHAN, "Incorporating the Other: The Catalogue of Women in Odyssey 11", Electronic Antiquity 2 (1994).

12 Most relevant are D. Reynolds, Heroic poets, poetic beroes: the ethnography of performance in an Arabic oral epic tradition, Ithaca, 1995, and S. SLyomovics, The Merchant of Art: an Egyptian Hilali oral epic poet in performance, Berkeley, 1987.

13 On rhapsodes as recomposers-in-performance, see G. NAGX, Pindar's Homer, Baltimore, 1990, p. 21-29 and Id., Poetry as Performance, Cambridge, 1996, p. 59-86.

14 See the apparatus in Monro and ALLEN's Oxford editio minor (1920) ad Il. II, 484ff. 
some versions of the Iliad segued into the Aitbiopis. ${ }^{15}$ Closer to the texts at hand in this discussion: the Hesiodic Theogony in at least a few manuscripts does not end sharply, but instead continues with what we recognize as none other than the Catalogue of Women (lines 1021-1022 in West's edition). West in the case of the Theogony wants to see this as a mechanical importation, perhaps from a scholion or ancient book tag. ${ }^{16}$ But I suggest instead that in all these cases what we are seeing is neither scribal nor editorial practice (which at any rate it would be hard to motivate). These segues and omissions bear the marks of actual performance conditions; they could well be remnants of rhapsodic practice, the live-performance "stitching together" of songs that is alluded to in the contest of Homer and Hesiod, and to which $\mathrm{fr}$. $357 \mathrm{M}-\mathrm{W}$ must refer: ${ }^{17}$

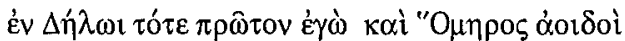

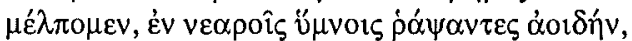

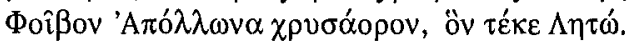

In Delos, then, first Homer and I as singers made music, stitching a song in new compositions concerning Apollo of the golden dagger, whom Leto bore.

I am proposing the following scenario: just as some performers of the Theogony could prolong their singing or recitation with the Catalogue of Women (as the textual evidence suggests) so Odysseus the performer creates suspense in the midst of Odyssey XI using precisely this kind of catalogue material. The intertextual effect attunes an audience to yet another external resemblance. For at this point in the poem, rather than looking like an itinerant story teller or poet, Odysseus, to an audience that knows rhapsodic repertoires, looks like a rhapsode. If, as seems likely, the performer of our Odyssey was also, at some stage in the transmission, a rhapsode, the ironic mirroring effect would be all the more striking.

At this juncture, we are enabled to circle back to Orpheus. It is well known that at least one poem called Descent to Hades was associated with his name - perhaps several. In these compositions, which West thinks stem from the late 6th century, it appears the poet recounted, in the first person, all that he saw on the trip down to recover his dead wife. ${ }^{18}$ Obviously, the Odyssean Nekuia offers parallels in terms of theme. Wilamowitz long ago, followed more recently by Böhme, asserted that the entire Nekuia was an

15 O.c. ad $I l$. XXIV, 804.

16 M. WEST, Hesiod: Theogony, Oxford, 1966, ad loc.

17 On the implications of this fragment and on the stitching of verses, see R. MARTIN, "Synchronic Aspects of Homeric Performance: The Example of The Hymn to Apollo", in A. GonzÁlez dE ToBIa (ed.), Una nueva visión de la cultura griega antigua bacia el fin del milenio, La Plata, Arg, 2000, p. 403-432, with further bibliography.

18

On the katabases, see West, Orpbic poems (cit. n. 4). 
interpolation by an editor interested in Orphism. ${ }^{19}$ By contrast, we can imagine a case of "performance interaction" that would not depend on a scribe copying a pre-existing text, but on the fact of one performer responding to contemporary and competing repertoire traditions. ${ }^{20}$ If the Orpbic Descent to Hades circulated not just privately, but in public rhapsodic performance, the very existence of the Nekuia in Book 11 may well represent a response to this competitive pressure. The much-noticed incongruities that have led Analysts to see massive interpolation might then be the result of an Odyssey performer's attempt to appropriate the latest popular performance topics in his community.

While we have no direct evidence for such an appropriation (even though it is a common occurrence in comparative oral traditions), the dynamic of the Odyssey episode again provides a lead. In Book XI, Odysseus's "catalogue" of women features one crucial difference that brings it closer to a sacred narrative by a poet who has made a descent to the underworld (as in the supposed Orphic accounts). From the proem of the Hesiodic catalogue, we can see that the performer calls on the Muses in language similar to that in Iliad II, 484ff, the introduction to the Catalogue of Ships:

\section{P. Oxy. 2354, ed. Lobel}

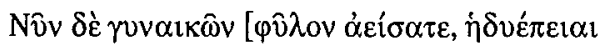

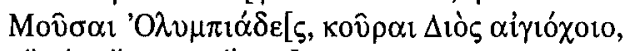

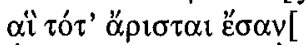

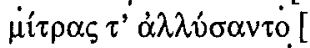
$\mu \imath \sigma \gamma o ́ \mu \varepsilon v \alpha \imath \theta \varepsilon o i \sigma[\mathrm{lv}$

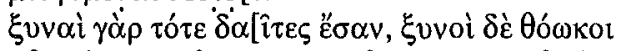

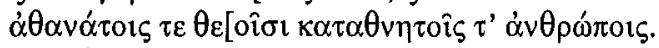

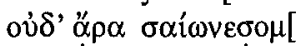

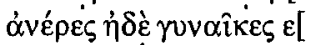

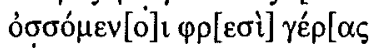

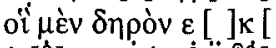

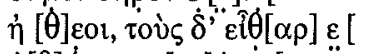

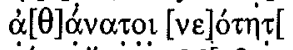

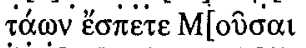

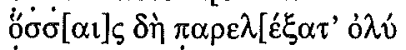

\section{II, $484-487$}

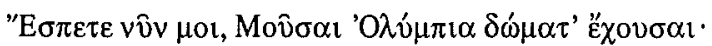

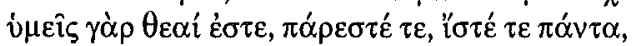

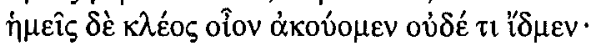

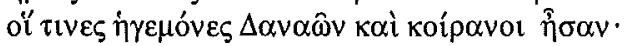

19 See R. Вӧнме, Orpbeus: Der Sänger und seine Zeit, Bern, 1970, p. $31-59$ with reference to earlier work.

20 For other indications of such responsiveness, see MARTin, Language of Heroes (cit. n. 1), p. 225-230. 
Contrast the opening of Odysseus's list, with its stress on the autobiographical "I"

od. XI, 225ff.

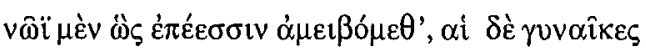

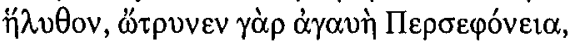

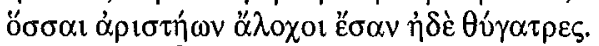

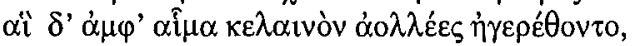

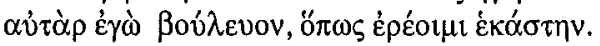

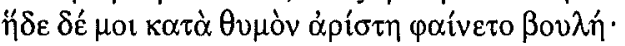

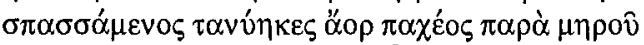

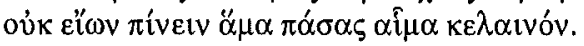

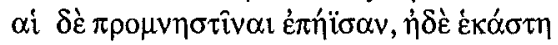

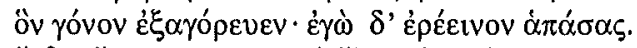

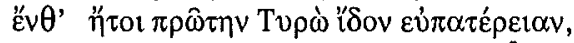

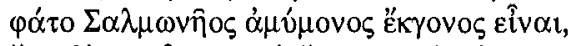

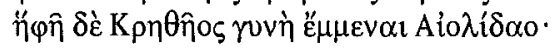

With his repeated insistence on sight throughout the passage (XI, 235, $260,266,271,281 ; 298,306,321,326$ ) Odysseus makes the claim of autopsy that the Iliad performer, in the splendid recusatio of Iliad II, 484ff., declines to make, and that the Hesiodic performer also foregoes. In other words, Odysseus trumps both strategies. He has been to Hades and back, and lived to tell. He has seen what others only hear about.

The phenomenon would be parallel, in my understanding, to the assertions that the Iliad in Book II (N.B.: within another catalogue) makes about the fate of the poet Thamyris. In the terms of Homeric poetry, in competition with Herakles traditions, the bard Thamyris, and by implication poets who claim to recite his words, is defective, a loser to the Muses. ${ }^{21}$ For the evidence that there must have existed such later performers of poetic traditions attributed directly to Thamyris, we can refer once more to the passage of Plato's Ion with which I began. It is worth noting that the gigantic Underworld painting by Polygnotos in the Cnidian Lesche at Delphi, dating to the mid-5th century BCE, portrayed Thamyris as blind and dejected, with a broken lyre at his feet. In the same part of the painting, says Pausanias, Orpheus was depicted playing a kithara, with an attentive group of hearers nearby. ${ }^{22}$ This representation, I suspect, produced a similar message of poetic denigration concerning Thamyris, but this time with Orpheus instead of Homer as the privileged poet of the pair.

We know that Hesiodic poetry was in the rhapsodic repertoire; I have argued that the Homeric catalogue in Book XI responds to the Hesiodic form of catalogue narrative in a challenging, competitive way. My suggestion now

21 See Martin, o.c., p. 229 .

22 Pausanias, X, 30; see R. Kenric, The Paintings in the Cnidian Lesche at Delphi and their Historical Context, Leiden, 1983, for full details and bibliography. 
is that the Odyssey also responds and rises to the challenge of Orphic material - the autobiographical descent of the poet - although the full range of performance contexts for such poetry is hidden from our view. The other evidence to support my idea that Orphic poetry was rhapsodic is circumstantial. Leaving aside the question of the late "rhapsodic" Theogony as a puzzle with an intriguing attribution, we might focus instead on an individual first, the infamous Onomakritos. Several testimonia associate him with Orphica, as also with a Peisistratean project to fix Homeric poetry. ${ }^{23}$ The question is: was he also a rhapsode? That he was a poet, at least, is argued by Gregory Nagy who observes that the story of Onomakritos being caught while forging oracles fits with the assumption that he was a professional rival of the poet Lasus of Hermione. ${ }^{24}$ In addition to this, I note that Onomakritos is explicitly associated by Plutarch with another character, the mysterious Kunaithos. From the precious scholion to Pindar, Nemean 2 (1c), we know that Kunaithos was certainly a rhapsode:

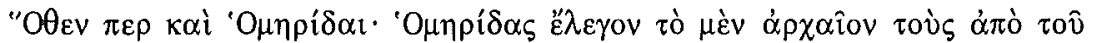

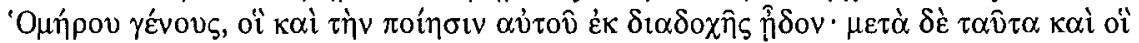

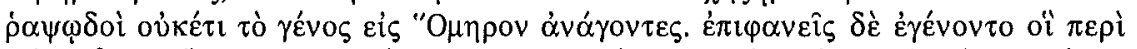

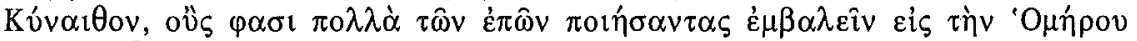

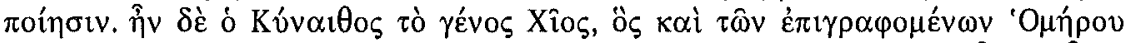

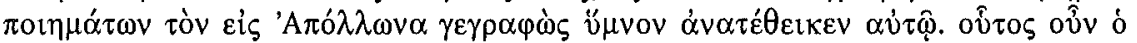

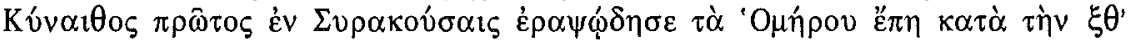

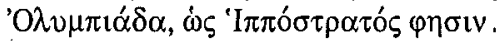

From the point of view of later generations, even in the 5 th century, by which time rhapsodizing had been standardized and subject to further rules, the expansion and experimentation on traditional material as done by a Kunaithos and an Onomakritos could only be branded as forgery or falsification - hence the tone of the testimonia. It is significant that the one interpolation attributed to Onomakritos within the text of Homer as we have it is precisely in the Odyssey XI underworld scene, as mentioned in the scholia to line XI, 604:

\section{Scholia to Od. XI, 604}

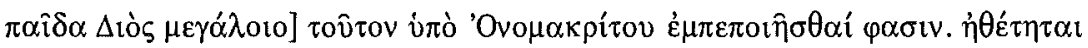

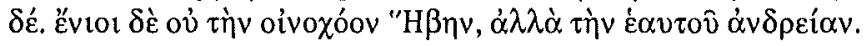

It would make sense if Onomakritos, as a rhapsode of Orphic material, would have had an interest in fine-tuning a scene of katabasis. This does not imply, however, that Onomakritos as an "editor" interpolated the Nekuia.

23 See F. Stoessl, "Onomakritos", $R E$ XVIII (1939), col. 491-493.

24 NAGY, Pindar's Homer (cit. n, 13), p. 172-174 and ID., Poetry as performance (cit. n. 13), p. 104-105. 
A second piece of circumstantial evidence for the widespread, rhapsodic performance of Orphica is one of the most obvious: the Orphic theogonic passage of Aristophanes Bird (lines 693-702). ${ }^{25}$ If such theogony material was in fact only in limited circulation for a literary elite, of the sort West hypothesizes, how could Aristophanes have expected the audience of his comedy to get the point? Even if it is, as West argues, a question of borrowed motifs - how did people know the motifs? Rhapsodizing Orpheus assuming that Orphic material was public, performed, and popular - could provide the answer.

The final piece of circumstantial evidence brings us to myth, and especially mythic projection of performances. It has been convincingly argued by Nagy that much of what we know from the testimonia and poetry about Homer and Hesiod is in fact a retrojecting strategy employed by the very rhapsodic tradition that transmits their poetry. ${ }^{26}$ It so happens that we have several intriguing stories about Orpheus as well, specifically about his role as poet. Aside from the stories that attest to the power of his kithara playing while he lived (and which are probably connected to the lore and ideology of actual kithara-performers) there are the post-mortem tales. His severed head keeps on singing; a shepherd who sleeps by his tomb sings with the voice of the dead poet; the dead Orpheus or his head is credited with oracular powers. ${ }^{27}$ As well as being a powerful image of the survival of oral tradition, one with rich comparative connections in Irish and Indic lore, this myth complex can equally be a rhapsodic construct, the obverse of the way in which Homeric poetry tends to denigrate Thamyris. It is a strategy for giving status and a patina of prestige to one's performances. To say that Orpheus's head keeps on singing is another way of expressing a sociopoetic fact, that audiences and performers kept on singing and performing "Orpheus" stories and poems attributed to him. In fact, this was the claim that Terpander, a key figure in the development and performance of kitharodic epic, must have made in his own work, perhaps in the 7 th century. Ps-Plutarch De Musica $(5,1132)$ cites Alexandros (273 F 77 Jacoby) to the effect that Terpander "took as models (ezêlokenai) the hexameter verses of Homer and the melodies of Orpheus." Again, there is no absolutely direct evidence; one might object that Terpander is not a rhapsode, but in this story, it seems he is quite close to being one. As an inventor of kitharodic nomes, and singer of hexameters, he might even be considered a genetic link between older poets and 6th century performers. To make a mimesis of Orpheus, as Terpander did, is to perform at the outer limits of influence, in effect to be a first imitator: Orpheus mimed no one, we are told (De musica $5,1132)$. That sense of reconnecting with a distant past, an aboriginal song, in

25 See N. Dunbar, Aristopbanes Birds, Oxford, 1995, p. 437-447.

26 NAGY, Homeric Questions (cit. n, 1), passim.

27 For full details and comparative materials, see J. NAGY, "Hierarchy, Heroes and Heads", in L. Edmunds (ed.), Approaches to Greek Myth, Baltimore, 1990, p. 199-239. 
turn must have cast a glow over the mutbos-making public performances of rhapsodes in archaic Greece. If a performer could manage to reproduce Orpheus, miming his melodies, then an audience, no matter how stolid, might respond as though charmed - surely a wish that any Ion might cherish.

Dept. of Classics

Richard P. MARTIN

Bldg. 20, Main Quad

STANFORD, CA 94305

USA 